\title{
Osteogenesis of Adipose-Derived Stem Cells
}

\author{
Brian E. Grottkau, Yunfeng Lin*
}

Department of Orthopaedic Surgery, MassGeneral Hospital for Children and the Pediatric Orthopaedic Laboratory for Tissue Engineering and Regenerative Medicine, Harvard Medical School, Boston, Massachusetts, USA

Current treatment options for skeletal repair, including immobilization, rigid fixation, alloplastic materials and bone grafts, have significant limitations. Bone tissue engineering offers a promising method for the repair of bone deficieny caused by fractures, bone loss and tumors. The use of adipose derived stem cells (ASCs) has received attention because of the self-renewal ability, high proliferative capacity and potential of osteogenic differentiation in vitro and in vivo studies of bone regeneration. Although cell therapies using ASCs are widely promising in various clinical fields, no large human clinical trials exist for bone tissue engineering. The aim of this review is to introduce how they are harvested, examine the characterization of ASCs, to review the mechanisms of osteogenic differentiation, to analyze the effect of mechanical and chemical stimuli on ASC osteodifferentiation, to summarize the current knowledge about usage of ASC in vivo studies and clinical trials, and finally to conclude with a general summary of the field and comments on its future direction.

Keywords: adipose derived stem cells; osteogenesis; bone tissue engineering; osteogenic differentiation

Bone Research (2013) 2: 133-145. doi: 10.4248/BR201302003

\section{Introduction}

Mesenchymal stem cells (MSCs) are a group of multipotent adult-derived stem cells that can be isolated from organs and tissues including bone marrow, ligaments, muscular and adipose tissue (1-2). MSC s may undergo self-renewal for several generations while maintaining their capacity to differentiate into skeletal muscle, smooth muscle fat, cartilage, connective tissues, tendon and bone (3). Within bone marrow, mesenchymal cells are located in the stromal compartment and are unique from the hematopoietic compartment. These cells harvested from the marow compartment of bone were named bone marrow derived mesenchymal stem cells (BMSC s), as one of the earliest multi-potent stem cells attracting researchers' attention ,which have been used for tissue engineering for years, including the study of bone formation for the spine (4-6). However, BMSCs harvest requires aspiration from the iliac crest

*Correspondence: Yunfeng in

E-mail: yunfenglin@scu.edu.cn

Tel: 86-28-85503487; Fax: 86-28-85582167

Rec eived 08 November 2012; Accepted 12 April 2013 which only yields $10-40 \mathrm{~mL}$ of marrow or from bone marrow biopsies, both of which can be painful, and the stem cell incidence in bone marrow is estimated to be about 1 per 105 cells (7). This constraint has led to the study of stem cells derived from adipose tissue.

Fat has long been felt to be an inert tissue, and lipoaspirate has been discarded as surgical waste. The numerous cell types in lipoaspirate, including preadipocytes, adipocytes, fibroblasts, endothelial cells and resident monocytes, vascular smooth muscle cells or pericytes, lymphocytes and macrophages (8), had been ignored in the past. Within the stromal vascular layer, researchers have begun to investigate a vast population of cells with the potential to differentiate into mesodermal tissues. In 2001, Zuk et al firstly established ASCs as a multipotent stem cell population, with the ability to assume osteogenic as well as chondrogenic, adipogenic, and neurogenic phenotypes, through chemically induced differatiation $(3,9)$. In contrast to BMSCs, ASCs have abundant and autologous cell source, carry relatively lower donor site morbidity, grow fast, and are available in large number of stem cells at harvest from a small volume of adipose tissue (10). As a 
result, $\mathrm{ASC}$ s have become an attractive and altemative multipotent cell population for use in tissue replacement therapies.

Bone tissue engineening offers a promising method for the repair of bone deficiencies caused by fractures, bone loss, and tumors. At present, the clinical gold standard for the treatment of skeletal defects is an autogenous bone graft. For the autogenous sources from which to harvest bone grafts are limited, clinicians have tumed to allogenic bone substitutes such as demineralized bone matrix consisting of extracelluar matrix proteins and growth factors without any cells, while the growth factors release is limited in duration failing to provide long term. The shortcomings of current methods indicate the need to combine cells which can form bone. ASC s have been demonstrated to undergo osteogenesis rapidly and with minimal stimulation by exogenous cytokines and thus be regarded as a promising option for bone tissue engineering tria ls (11). In this review, we will introduce how they are harvested, examine the characterization of ASCS, review the mechanisms of osteogenic differentiation, analyze the effect of mechanical and chemical stimuli on ASC osteodifferentiation, summarize the current knowledge about usage of ASC in vivo studies and clinic al trials, and finally conclude with a general summary of the field and comments on its future direction.

\section{Harvest and culture of ASCs}

The methods gaining ASC s from different species have some differences. We will introduce the method of harvesting ASC sfom mice.

ASC $s$ isolated from inguinal fat pads of mice are harvested as follows. Eight-week-old BALB/c mice were used in the study, in accordance with the Intemational Guiding Principles for Animal Research (1985). All surgical procedures were perfomed under approved anaesthetic methods using Nembutal at $35 \mathrm{mg} \cdot \mathrm{kg}^{-1}$. Inguinal fat pads were havested from the mice and extensively washed with sterile phosphate-buffered saline (PBS) to remove contaminating debris. Then, they were incubated with $0.075 \%$ type I collagenase in PBS for $60 \mathrm{~min}$ at $37{ }^{\circ} \mathrm{C}$ with agitation. After removing of collagenase by dilution with PBS, cells released from adipose specimens were filtered through a $100 \mu \mathrm{m}$ mesh to remove tissue debris, and collected by centrifugation at $1200 \mathrm{~g}$ for $10 \mathrm{~min}$. This results in separation of harvested fat into three layers: infranatant (lowest layer composed of blood, tissue fluid and local anaesthetic), middle portion (primarily fatty tissue), and supranatant (upper layer, least dense and consisting of lipids). The pellet from the infranatant wasresuspended and incubated to remove contaminating red blood cells. And then, it was washed three times with PBS and seeded on the plastic tissue culture dishes in growth medium containing aMEM, 10\% fetal bovine senum (FBS), $100 \mathrm{U} \cdot \mathrm{mL}^{-1}$ penicillin, and $100 \mathrm{mg} \cdot \mathrm{mL}^{-1}$ streptomyc in. ASC s were maintained in a humidified atmosphere of $5 \% \mathrm{CO}_{2}$ at $37{ }^{\circ} \mathrm{C}$. They would be passaged three times prior to osteogenic differentiation. After transferred into speci ficmedium containing dexamethasone $\left(10^{-8} \mathrm{~mol} \cdot \mathrm{L}^{-1}\right)$, ascorbic acid $\left(50 \mathrm{mg} \cdot \mathrm{L}^{-1}\right)$, and $\beta$-glycerophosphate $\left(10 \mathrm{mmol} \cdot \mathrm{L}^{-1}\right)$, the ASC s showed obvious phenotype alteration and tumed to osteogenesis. The medium was replaced every 3-4 days for 14 days till differentiated cells were confluent (Figure 1).

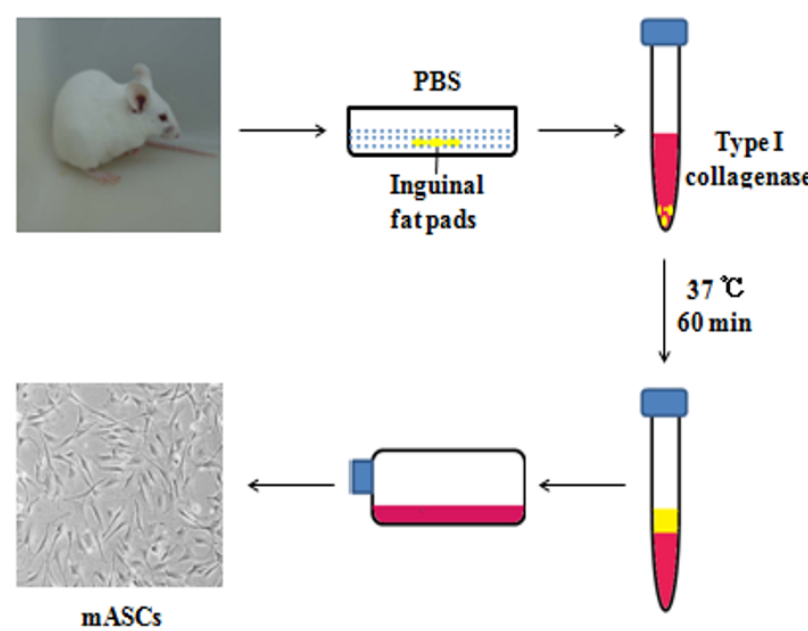

Figure 1 Isolation of adipose-derived stem cells.

\section{Characterization and localization}

ASCs display fibroblast-like morphology and preserve their shape after expansion in vitro. Similar to other types of MSCs, ASC s remain difficult to define due to lack of definitive cellular markers. Mitchell et al found that stromal cell-associated markers, including CD13, CD29, CD44, CD63, CD73, CD90, CD166, were initially low on stromal vascular fraction (SVF) cells and increased signific a ntly with suc cessive passages (12). Dominici et al demonstrated that ASC s must express CD105, CD73 and CD90, and lack expression of CD45, CD34, CD133, CD14 or CD1lb, CD79a or CD19 and HLA-DR surface molecules (13). Lin et al found that ASCs exist as CD34+/CD31-/CD104b-/SMA- cells in the capillary and in the adventitia of larger vessels (14). Researchers also found a nother interesting characteristic of ASC s that the surface immunophenotype partially changes in different passages. At the early passages (primary to 4th) of ASC the hematopoietic-associated markers (CD11a, CD14, 
CD45, CD86 and HLA-DR) decreased and the MSC sassociated markers (CD13, CD29, CD34, CD44, CD63, CD73, CD90 and CD166) increased signific antly $(12,15)$. In general, markers that are unifomly reported to have strong positive expression a re CD13, CD29, CD44, CD73, CD90, CD105, CD166 and MHC-I, while markers of the hematopoietic and angiogenic lineages, such as CD31, CD34, CD45, CD117 (16), CD133 and STRO-1, have been reported to show low or lack of expression on ASCS. MHC-II has also been found to be absent on ASCS. Moderate expression has been reported for markers CD9, CD49d, CD106 and CD146.

\section{Mechanisms of osteogenic differentiation}

The osteogenesis process is not completely understood, it has been paid increasingly attentions on the molecular mechanisms recently. Researchers believe that osteogenesis is defined by a series of events which starts with a commitment to an osteogenic lineage by mesenchymal cells. And then, these cells proliferate and demonstrate an up regulation of osteoblast-specific genes and mineralization. After attachment, the medium of ASC s was then changed to basic osteogenic differentiation medium (b-ODM) conta ining a-MEM, 10\% FBS, $100 \mathrm{mg} \cdot \mathrm{mL}^{-1}$ of ascorbic acid, $10 \mathrm{mmol} \cdot \mathrm{L}^{-1} \beta$ glycerophosphate. Retinoic acid can be supplemented to promote mASCs differentiation but is not necessary forhASCs.

The mechanisms of driving the ASCs into the osteoblast lineage are still not clear, researches on signaling pathways have provided much information on the effect of signaling molecules on cell migration, adhesion, proliferation, differentiation, and ultimately bone formation. Multiple signaling pathways have been demonstrated to participate in the differentiation of an osteoblast progenitor to a committed osteoblast including transforming growth factor- $\beta$ (TGF- $\beta$ )/bone morphogenetic proteins (BMPs), Wnt/ $\beta$-Catenin, Notch, Hedgehog and Fibroblast Growth Factor (FGF), etc .

BMP is a member of the TGF- $\beta$ superfamily except BMP-1, it was originally isolated from bovine bone extracts and found to induce ectopic bone fomation subcutaneously in rats (17). This group of proteins includes sixteen BMPs and comprises nearly one-third of the TGF- $\beta$ superfamily. Studies have demonstrated that it is a promising candidate cytokine in osteoblast differentiation and osteogenesis. BMP initiates its signaling cascade through ligand binding to the heteromeric complex of types I and II serine/threonine kinase receptors on the cell surface (18). Subsequently, these activated receptor kinases phosphorylate transcription factors signaling mothers against decapentaplegic (Smad) proteins 1, 5 and 8 (19). These phosphorylated Smads form a heterodimeric complex with Smad4 and effect target gene expression and promote the osteogenic differentiation. BMPs have also been shown to increase transcription of core-binding factor-1/Runtrelated family 2 (Cbfa1/Runx2), a molecule known to be necessary for commitment along an osteoblastic lineage, to regulate osteoblast differentiation (20) (Figure 2). The 16 subtypes of BMPs are observed to express obviously in relevant tissues, such as BMP-2 expresses in cartilage, periosteum and compactbone; BMP-2,-4,-7 show good bone-forming activity when combined with collagen, hydroxyapatite (HA) and degradable high molecular polymer (HMP) in different a nimal bone defects experiments (20). In general, BMP-2, 4, 6, 7 and 9 are considered to be the most osteoinductive (21). However, the osteoinductive effect of BMPs is affected by some factors. Some studies found that BMPs are more potent at inducing bone formation as heterodimers than as homodimers. In culture, BMP-2/6, BMP-2/7, and BMP-4/7 heterodimers have been shown to promote higher alkaline phosphatase levels than homodimercombinations in vitro and in vivo (22-25). The effect of BMPs has also been noted to be concentration dependent. At low concentrations, they foster chemotaxis and cellular proliferation, while BMPs induce bone

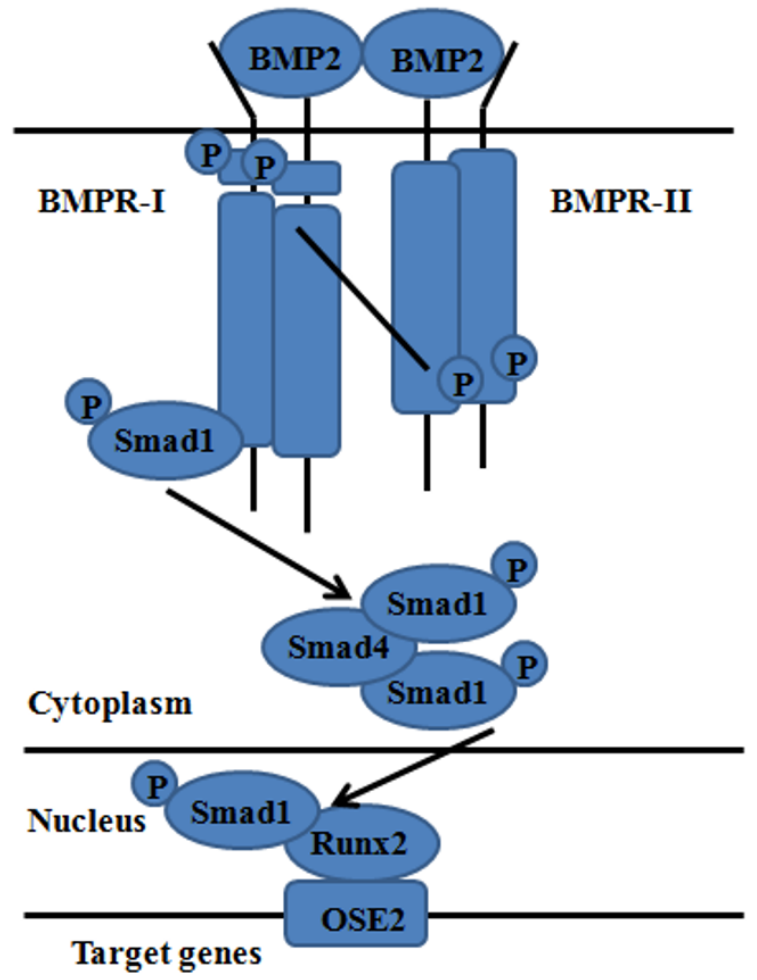

Figure 2 BMP Signal and osteogenesis of adipose-derived stem cells. 
formation at high concentrations (26).

Among the subtypes of BMPs, BMP-2, as a pleiotropic regulator, govems the key steps in bone induction cascade such as chemotaxis, mitosis, and differentiation of mesenchymal stem cells in the process of bone healing (27-28). Although some reports described the effectiveness of BMP-2 for the osteogenesis in BMSCs and ASCs, it is unclear whether BMP-2 enhanced ASC S can heal the large bone defects (29-30). In our previous study, ASCs were harvested from nomal SpragueDawley (SD) rats and transfected by BMP-2 gene before they were loaded on alginate. The ability of bone regeneration was detemined in rat critical-size cranial defects, which were 8-mm diameter defects created in the calvarias of 36 rats. These rats were divided into three groups. In experimental group, the defects were filled with alginate gel combined with BMP-2 transfected $A S C s$; in negative control group, the defects were filled with alginate gel mixed with nomal ASCs; in blank controls, the defects were filled with cell-free alginate gel. Four rats of each group were killed and the cranial defect sites were observed at 4, 8 and 16 weeks after surgery. At 4 weeks in experimental group, the initial resorption of alginate scaffolds was clear and the newly formed bone extended. The consolidated whitish bone was found within the defect margin in experimental group from 8 weeks on. At 8 weeks, there was a great extent of reduction of cranial defects and they accomplished complete osseous healing at 16 weeks when the experiment finished. The bone formation in the negative control groups was only presented disordenly along the periphery of the defects and the central domain showed fibrous healing. There was few new bones formation at the blank control group. To clarify the molecular events leading to the formation of new bone, we investigated expression of biochemical markers using RT-PCR and westem blotting along the course of BMP-2 enhanced ASCs differentiation. The RT-PCR analysis of OCN, OPN, RUNX2 and BMP-2 demonstrated that there was significant difference in expression between experimental and control groups. Continued high expression of OCN, OPN, RUNX2 and BMP-2 was observed throughout the progression of the experiment group both in vitro and in vivo. In negative control groups, these genes were not observed in vitro and 8 weeks in vivo, only at the 16 weeks after surgery, weak expression of these genes was observed; in the blank control group, these genes were not detected at 8 and 16 weeks. The westem blotting analysis was similar to the RT-PCR results. In the experiment group, these proteins were observed in the monolayer cells after BMP-2 transfection in vitro and in vivo, but not observed in the negative and blank control groups. Our research demonstrated that load-bearing alginate with BMP-2 enhanced ASCscan repair the large bone defects, and therefore applied in the bone tissue engineening for further clinic al usage (31).

The Wnt family consists of a large number of secreted glycol-proteins that are involved in embryonic development, tissue induction, and axis polanity (32-33). Most Wnt proteins are thought to act as ligands for cell surface receptor complexes composed of frizzled (Fz) and low-density lipoprotein (LL)-receptor-related protein $5 / 6$ (LRP5/6) family members. Downstream of FzLRP5/ 6 complexes, canonical Wht signaling results in stabilization and translocation of $\beta$-catenin to the nucleus, where it binds to T-cell factor/lymphoid enhancer factor (TCF)/Lef transcription factors (Figure 3). $\beta$-Catenin-TCF/Lef complexes a ctivate transcription of a variety of Wnt-responsive genes, including genes involved in proliferation, osteoblast differentiation and osteogenesis (34-36). Deregowski's report observed that Notch-1 overexpression inhibited osteoblastogenesis by suppressing Wnt/beta-catenin but not BMPs signaling (37). Chen et al found that alcohol not only inhibits mature osteoblast activity but also influences the balance between osteoblast and adipocyte differentiation and mesenchymal stem cell commitment in bone marrow. Their observations are consistent with the

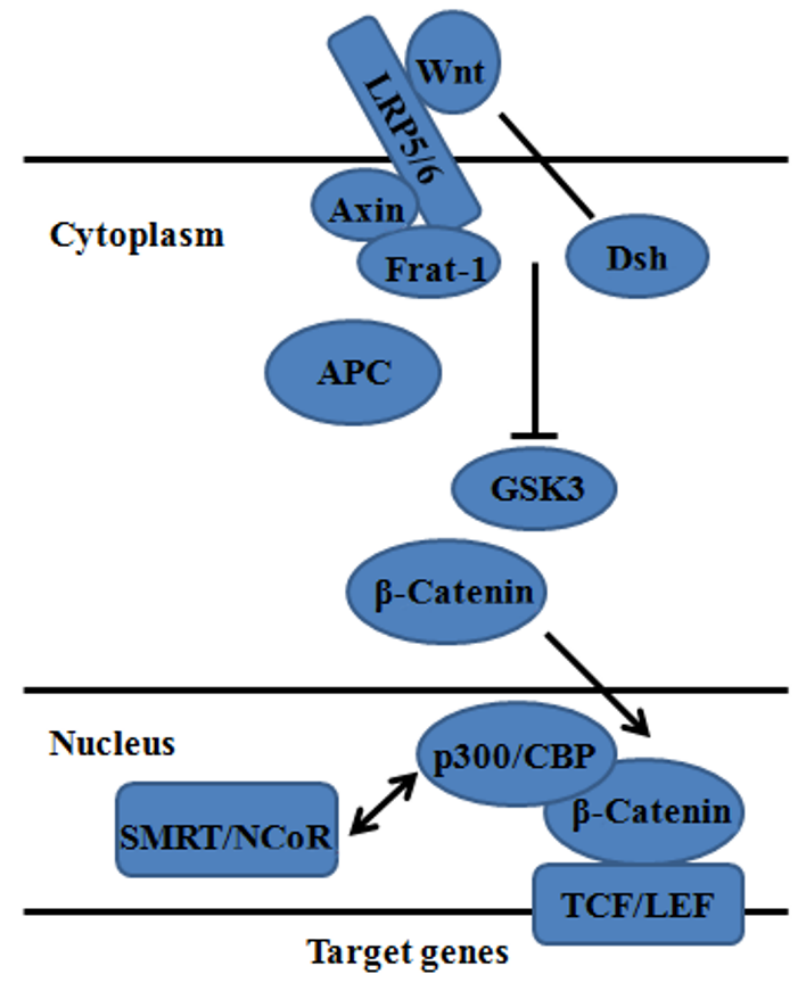

Figure 3 Wnt Signal and osteogenesis of adipose-derived stem cells. 
hypothesis that eetha nol inhibits bone formation through stimulation of oxidative stress to suppress Wnt signaling (38). Si et al found that tightly regulated CCN1/Cyr61 expression may play an important role in Wnt3Ainduced osteoblast differentiation of mesenchymal stem cells (39). Stevens et al indicated that Wnt10b, as the only Wnt ligand linking to mesenchymal progenitor function in both humans and mice, is uniquely required for maintenance of mesenchymal progenitor activity in adult bone (40). Some studies revealed that noncanonical Wnt signaling could also play a role in osteogenic differentiation. Such as, non-canonical Wnt5a signaling involving Ror2 and Rho A as well as $\mathrm{N}$-c adherin mediated $\beta$-catenin signaling are necessary for mechanically induced osteogenic differentiation (41). And Wnt-4may have a potential use in improving bone regeneration and repair of craniofacial defects (42).

Notch signalling plays a critical role in development and regeneration of stem/progenitor cells as well as in controlling their fate (43-46). The Notch system is known to be an evolutionarily conserved mechanism that balances proliferation and differentiation of stem/ progenitor cells (47). Previous investigations showed Notch signaling positively regulated the osteoblastogenesis in several kinds of cells, such as ST-2 marrow stromal cells (37), murine bone marrow mesenchymal progenitors (48), osteoblastic cells M3T3-E1 (49), mesenchymal progenitor cells Kusa (50), C2C 12 myoblasts (51) and COS-7 cells (52). The Notch receptor is a single pass trans-membrane protein which, during maturation, may be cleaved by a furin-like convertase (at S1) in the trans-Golgi to generate a noncovalently associated heterodimer at the cell surface. Canonical Notch signalling is initiated when a cell-surface expressed Delta/Serrate/LAG-2 (DSL) ligand binds to the Notch receptors (Notch-1, -2, -3 and -4) expressed on an opposing cell surface. Endocytosis of the Notch-ligand complex by the ligand-expressing cell leads to ADAM metalloprotease mediated cleavage at $\$ 2$ and removes the extracellular fragment of the heterodimer. The membrane tethered fragment is then cleaved by $\gamma$-secretase complex at S3 to release the Notch intracellular domain (NICD). This transports to the nucleus and assembles into a transcriptional activation complex, CCAAT-binding protein (CBF-1), which includes a DNA binding protein of the CSL family and its co-activator Mastemind-like (53). This new assembly acts as a transcriptional repressor without existence of NICD, which recruits a co-repressor complex and inhibits transcription of target genes that containing CCAAT binding sites (54-55). As a sequence of binding, NICD displaces the repressor complex of CSL and recruits nuclear co-activators, such as mastemind-like 1 (MAML1) and histone acetyltransferases (56), converting CSL into a transcriptional activator. Notch activation through CSL-NICD interactions can in tum activate transcription of various target genes, including Hes (Ha iry Enhancer of Split) (57), Hes-related repressor protein (HERP) (58-59), per-oxisome-proliferator-activated receptor (PPAR) (60) and nuclear factor-kB (NF-KB) (61) (Figure 4). In addition to trans-activating Notch-ligand complexes, the receptor can also form cis-inhibitory complexes when Notch and ligand are expressed on the same cell surface. Cis-inhibition serves to limit the zone of Notch activity and is particularly important in developmental programs in Drosophila such as the wing disc and eye (53).

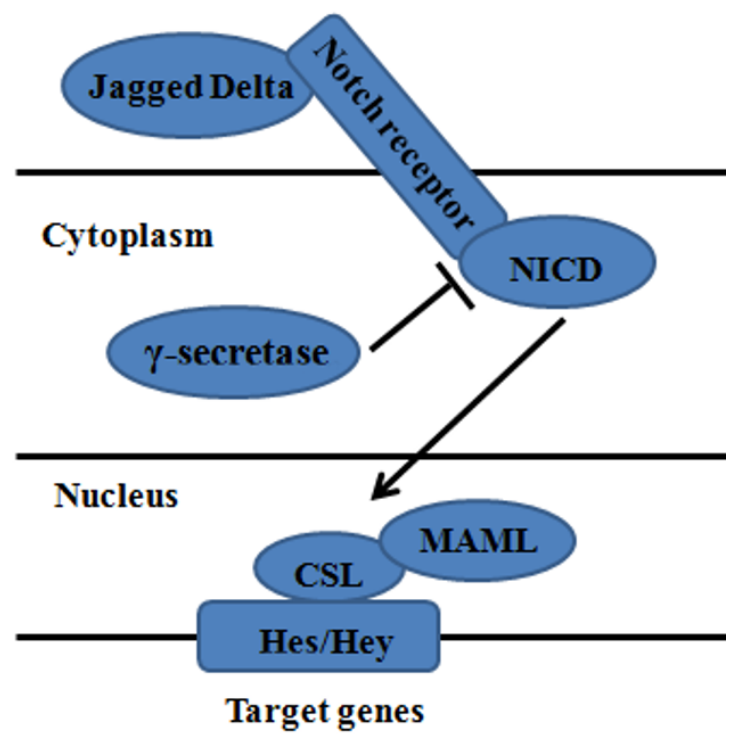

Figure 4 Notch Signal and osteogenesis of adipose-derived stem cells.

$\mathrm{N}$-[N-(3,5-Difluorophenacety I)-L-a la nyl]-S-phenylglyc ine t-butyl ester (DAPT) is a $\gamma$-secretase inhibitor that can block Notch signaling by preventing the cleavage of Notch receptors, which has been widely used to evaluate the biological behaviors and Notch signaling pathway in various cells such as muscle stem cells, neural stem cells, BMSCS, human tongue carcinoma cells, etc (62). Our group investigated the effects of DAPT on proliferation and osteogenesis in ASC s for the first time by using an in vitro 1,25-Dihydroxyvita min D3 (VD3) induced osteogenic differentiation system. The DAPT treated cells showed a dose-dependent increase compared to non-DAPT group. Results indicated that the addition of DAPT to VD3 treatments signific antly increased osteogenesis in ASCs. In this study, we attempted to assess the biological effects of DAPT on the proliferative capacity of ASCs. Results showed that 
ASC s cultured in DAPT significantly decreased in CFU numbers compared with those cultured in control medium during 2-week culture period. DAPT clearly inhibited ASC s proliferation at all doses, which revealed the inhibition of ASCs proliferation by DAPT and indicated that ASC s responded with decreased growth when the Notch pathway was blocked. Real-time PCR showed the expressions of Notch downstream target genes Hes-1 and Hey-1 were decreased significantly after DAPT trea tment. Immuno fluorescence staining also revealed that Hey-1, expressing in the nucleus of ASC s to act as a transcriptional repressor, was down-regulated when Notch signaling was inhibited by DAPT. While, Real-time PCR and Westem Blot showed expressions of the genes encoding osterix (OSX) or Runx2, as an essential transcriptor required for osteogenesis, increased during osteogenic induction in the presence of DAPT. These results indic ated that the Runx2 dependent osteogenic differentiation of ASC s was enhanced when the interaction between Runx 2 and Notch target gene Hey-1 was suppressed in the presence of DAPT (63). Previous study reported that Notch repressed osteoblastic differentiation through its target genes and Runx2 (64), whic h was similar to our results.

Hedgehog proteins, like Wnt proteins, are important signaling molecules which play critical roles in the control of pattem formation and cellular roles in the control of pattem formation and cellular proliferation/ differentiation (65). In vitro, Sonic Hedgehog (Shh) induces ALP expression (66-67), and also increases selectivity in the differentiation of multipotent mesenchymal cells into the osteoblast lineage (68). Thus, osteogenesis is a complex process that can likely be modulated by small molecules acting on a number of signaling pathways. Wu et al demonstrated that purmorphamine induces osteogenesis by activation of the Hedgehog signaling pathway (69).

FGF signaling participates in skeletal development from the earliest stages of limb bud development through the final stages of the ossification process. Several FGFs are expressed in the developing endochondral bone (70). FGF2 expression, which was first isolated from growth plate chondrocytes, has also been observed in osteoblasts and in periosteal cells. Despite the widespread expression of FGF2, targeted deletion of FGF2 caused a relatively subtle defect in bone, leading to decreased bone density, but no defects in skeletal size or patteming (71). In addition, no defects in chondrogenesis were observed, suggesting that if FGF2 is involved in chondrogenesis that it may be redundant with other FGFs (72). Both FGF9 and FG F18 a re expressed around the condensing mesenchyme and in the peri- chondrium/periosteum, which are also good candidates for redundant factors (73-74). The perichondrium also expresses FGF7, FGF8, and FGF17. Some or all of these FGFs may signal directly to chondrocytes in the growth plate (72). Genetic studies have identified a defect in chondrogenesis and osteogenesis in mice lacking FGF18 (75-76). Requirements for FG F7, FG F8 and FGF17 in skeletal development have not been identified. Homones can also influence the skeletal metabolism directly or indirectly. Parathyroid homone promoted bone growth or filled up lacunas caused by osteoclast when decomposing, or synthesizing bone while in mature bone tissue (77). Estrogen up-regulates the transcriptional expression of osteoblast-related genes such as BMP-2, ALP, TGF-1 and Cbal. Physiological concentration of glucocorticoid can stimulate osteoblast differentiation of MSCs. However, if applying with large dose of glucocorticoid in long period, osteoblast proliferation, apoptosis and reduction of active osteoblast-composition can be inhibited, and ultimately this may lead to osteoporosis.

\section{Osteogenesis of ASCs via stimulation}

In general, two major approaches have been used to regulate the mechanical environment of cells and tissue engineering constructs in culture: mechanical signals such as tensile, compressive strain, fluid shear and electric al stimulation, and biochemic al composition.

Mechanical force is a fundamental biological factor that stimulates fracture healing and bone remodelling processes (78), and most studies indicate that mechanical stress is an anabolic factor for osteogenic differentiation of BMSC s or osteoblasts (79-80).

Mechanical stretch has been believed to be a regulating factor of osteo-adipogenic axis differentiation of mesenchymal stem cells. In our previous study, mASCs, after being osteo-induced for $48 \mathrm{~h}$, were subjected to uniaxial cyclic tensile stretch by a 4-point bending mechanical loading device with the long duration continuous pattem ( $6 \mathrm{~h}$ cyclic stimulation for 1 day, $1 \mathrm{~Hz}, 2000 \mu \varepsilon$ ) and short duration consecutive pattem (17 min cyc lic stimulation a day for 10 days, $1 \mathrm{~Hz}$, $2000 \mu \varepsilon$ ). The results showed that mASC s a re sensitive to cyclic tensile strain. Compared to $17 \mathrm{~min}$ of consecutive stretching, cyclic tensile strain of 6 continuous hours' duration could signific antly increase gene expression of BMP-2 and Runx2 and depress OCN mRNA expression. We indicated that ASC s may sense mechanical loading in a duration-dependent manner and cyclic tensile stretch may modulate the osteogenic differentiation of ASC s via the BMP-2 signalling pathway (81). Moreover, 
we hypothesized that mechanical force was one of the pivots that modulate osteogenic differentiation, depending on the induction environment of progenitor cells. So we studied the differentiation of mASCs in adipogenesis-induced environment under mechanical stress. Cells were randomly divided into four groups. Loading groups were exposed to uniaxial cyclic tensile stretch for $2000 \mu \varepsilon, 1 \mathrm{~Hz}$ for 6 and $2 \mathrm{~h}$, respectively, a fter ASCs were adipo-induced for $72 \mathrm{~h}$. ASCs that were retained in adipogenic medium without being loaded were used as induced-control group. In the third group, ASCs were exposed to mechanical loading under the same conditions, but without prior induction, and correspondingly, the non-induced control (NIC) group was kept in static medium without any mechanical loading. We found that conversion of ASC s into adipocytes driven by adipogenic conditions can be inhibited by mechanical signals that also allow osteoblastic lineage selection, and ERK1/2 activation may be involved in this mechanical stress-induced transdifferentiation. Mechanical stress may function as a pivotal regulation factor in reciprocal relationships of osteogenic and adipogenic differentiation (82). Hanson et al demonstrated that ASC exhibit enhanced osteogenic differentiation when exposed to both continuous (10\% stra in, $1 \mathrm{~Hz}$ ) and rest inserted stra in (10\% stra in, $1 \mathrm{~Hz}$, 10 rest between each cycle) (83). A study also showed that tensile strain can mechanically mediate agerelated variations in $\mathrm{mASC}$ proliferation an differentiation potential (84).

Fluid flow and shear stress are believed to impose a physical signal on osteogenic proliferation and differentiation in both MSC and ASC (85-88). Some studies also found that fluid flow could increase dimensionality and cellular distribution throughout a scaffold material, enhance nutrient transport and create a more functional construct (88-89). And PFF had been found to be the direct osteogenic signaling via fluid shear in ASC $(87,90)$. Cyclic compression has been demonstrated to enhance osteogenic differentiation and bone formation in vitro and in vivo (91-93), but there has been lack of work on the effect of compression on ASC osteoblast differentiation.

As bone formation by implantation of ASC s must be preceded by the in vitro osteogenic differentiation of these cells, it is important to develop techniques to ensure a well characterized and consistent cell population following the differentiation process. ASC can be osteogenic differentiated by chemical stimulation using media supplements and growth factors to induce lineage specification, such as 1, 25-dihydroxyvita min D3 (VD3), dexamethasone, $\beta$-glycerolphosphate and ascorbic acid $(3,63,94)$. Besides, additional growth factors and components including BMP-2, growth and differentiation factor-5, retinoic acid, and tumornecrosis factor- $\alpha$ among others have also been researched as osteogenic stimulators (31, 95-97). However, the differentiation procedure has the shortcomings of requining additional culture time and steps including the use of large amounts of costly growth factors and some supplements which could be cytotoxic to cells, before implantation to achieve therapeutic efficacy. New methods are required in order to not only reduce the culture period, the amount of demanded growth factors, but also enhance the effic iency of osteogenesis and thus of bone regeneration. One approach is delivery of cytokines involving incorporation of these molecules into scaffolds such as liposome and microspheres. This makes the growth factor to be retained at the site of interest for an extended period while mainta ining its biological a c tivity. Moreover, eng ineered ASCs with gene transfection by various vinus-vectors have evolved to be an attractive option to ameliorate bone repair, especially large bone defects. Genes like Runx-2, BMP-2, BMP-4, BMP-7, or Osterix-transfected ASC $s$ are consiered to promote the bone fomation in vivo implantation (28-30).

\section{In vivo studies}

To adequately translate in vitro findings to the clinical rea $\mathrm{Im}$, robust in vivo data must be obtained to demonstrate the osteogenesis capacity of ASCs. In vivo, ASCs survive in low oxygen environments making them good candidates forcell-based therapies in which the oxygen supply may be limited during the post implantation period when a blood supply is lacking (98). However, ASC s sec rete angiogenic cytokines such as hepatocyte growth factor and vascular endothelial growth factor, which are considered to contribute to the angiogenic properties of ASC s (99). The transplanted ASC s produce cytokines and chemokines that act ashoming signals for endogenous stem cells and progenitor cells to the site of injury. Therefore, presence of ASCs may promote the osteogenic and angiogenic conditions of the construct in vivo (100).

Besides the cells, the molecular growth factors and components as we mentioned previously, the bone defect models and the scaffolds also play an important role in vivo study. The ideal model should represent the characteristic of clinical condition of the bone injury or defect. And there are several models such as rat criticalsize cranial defect models and long bone skeletal defect models, which are generally acknowledged in 
the area of ASCs in vivo studies. Biomaterial scaffolds can not only potentially provide a controlled environment protecting implanted cells from hamful stimuli and a highly modifiable vehic le for inductive factors, but also deliver genetic material and/or inductive biochemical cues, which allow for some degree of developmental control over the delivered stem cells (101). Many studies have combined biomaterial scaffolds with ASCs to repair bone defects, for example, biphasic calcium phosphate nanocomposite (NanoBCP) (102), poly (lactic-co-glycolic acid) (PLGA) (103), HA/tricalcium phosphate (TCP) (104), chitooligosaccharide (COS) (105), fibrin/HA (106), and so on. Prichard et al (107) examined cell coverage and cell function of ASCs on different biomaterials, including fibronectin, silic one rubber, dualligand, polyimide, oxygen plasma plus fibronectin and polyurethane. The results showed that cell attachment was very strong on both polyurethane and polyimide for all attachment methods. None of the attachment methods caused any differences in basic cell proliferation, metabolism, caspase-3 activity and intracellular ATP concentration. However, ectopic bone formation inside porous ceramic blocks revealed that material properties such as size, composition, geometry, porosity and microstructure might be important but not sufficient parameters for appropriate bone formation (108). Moreover, $\beta$-TCP granules, named as CEROS 82, have been in clinical use in Europe for over 20 years. And the investigations have been published conceming the clinical value of Chronosl $\beta$-TCP in bone environment (109).

Ourgroup has done some research on bone regeneration of ASC scombined with NanoBCP and alginate gel. NanoBCP is a composite biomaterial formed by microporous $B C P$ with NanoHA and $\beta-T C P$, which has high strength and porous structures. The NanoBC $P$ constructs containing osteogenic ASC s were transplanted to nude mice subcutaneously for 8 weeks to acquire the physiological behavior of induced ASCs during ectopic differentiation in vivo and rat critical-size cranial defects were taken as the model to determine the efficiency of engineered constructs in the generation of new bone in situ. Histologic al ana lysis of the retrieved specimens from nude mice in experimental group showed obvious ectopic bone formation and there were positive expression of osteopontin (OPN) and osteocalc in (OCN) at RNA and protein level. As for the cranial defects, there was complete repair in experimental group, but only partial repair in negative controls. Combining osteogenic ASCs with NanoBCP can lead to formation of ectopic new bone. Furthermore, the approach can also stimulate bone regeneration and repair for the large size bone defects. On the basis of the results we thought load-bearing NanoBCP with ASCs could therefore applied in the engineening approach for further clinical usage (102). The alginate gel is one of the most extensively applied biomaterials in bone tissue engineering, which have a high porosity, ideal porous structure, biodegradable, biocompatibility, and high affinity to water In the presence of calcium ions, the semisolid gel can be formed with cross-linking of alginate chains under mild conditions (31). The critical-size cranial defect is one that will not regenerate spontaneously during the term of an experiment, which was a defect of $8 \mathrm{~mm}$ diameter on the calvaria of a rat in our studies. However, some researchers believe that a $4 \mathrm{~mm}$ mouse parietal bone model can offer a reliable, ea sily replic ated and easily followed defect model (98).

In 2005, Cowan et al reported successful calvarial critical defect healing by in rat with implantation of ASC-seeded, apatite-coated PLGA scaffolds (110). In 2006, Conejero et al successfully repaired the surgic ally created palatal bone defects in rats by using osteogenically differentiated ASC on a PLA scaffold (111). Dudas et al used rabbit ASC s seeded on gelatin foam (GF) scaffolds to regenerate bone in the rabbit calvarial defects (112). In 2007, Yoon et al implanted osteogenically differentiated ASC-seeded PLGA scaffolds into critical-sized rat calvarial defects and found robust bone healing after 12 weeks (113). Cui et al repaired the cranial bone defects with ASC s seeded on coral scaffold in a canine model (114). In 2010, Lee et al found ectopic bone formation by implanting PLGA biodegradable scaffolds with BMP-2 (BMP-2-ASC) or BMP-2/ Runx2 genes (BMP-2/ Runx2-ASC) transfected ASC s into the dorsal subcutaneous spaces of the mice (115). These studies suggest that the osteogenic phenotype of pre-differentiated ASC is functionally maintained in vivo and that they can operate in regenerative capacity at a bone defect site.

\section{Clinical trails}

Based on so many in vitro and in vivo research results, cell therapies using ASC s are widely promising in various clinical fields, such as breast reconstruction and augmentation (116-117), facial lipoatrophy reconstruction (118), cardiovascular tissue regeneration (119), and craniofacial tissue $(98,120)$.

ASC s of patients' own would be an ideal cell source for bone tissue engineering, and autologous nonimmunogenic bone tissues could be easily regenerated with this approach for the repair of large size bone defects. And the defects of facial bones and the 
cranium have been demonstrated to heal or enhancing healing with the use of ASCs. However, many countries have not yet approved the use of ASCs. To date, only two clinical case studies about bone regeneration by hASC s have been reported. In the first case, the patient, a 7-year-old female, had sustained severe head injury in a fall accident, which led to a closed multifragment calvarial fracture. The calvarial defect was treated with autologous ASCs isolated and applied in a single operative procedure in combination with milled autologous bone from the iliac crest. ASC s were supported in defect area using a utologous fibrin glue, and mechanical fixation was achieved with two large, resorbable macroporous sheets acting as a soft tissue bamier. The new bone formation and near complete calvarial continuity was observed 3 months after the recons truction (120). Harvesting of bone tissue or a composite microvascular flap is frequently followed by morbidity and a donor site defect despite usua lly being in an area of lesser importance. Furthemore, a large amount of autologous blood is needed for plasmapheresis, which may in some cases be difficult to obtain. It is known that ASCs can secrete angiogenic factors that promote neovascularization and vessel-like structure fomation. In the second case, Mesimäki et al harvested autologous fat tissue from a 65-year-old male patient, who underwent a hemimaxillectomy 28 months earlier, due to a large keratocyst, expanded the cells in culture, mixed with BMP-2, and seeded them on a $\beta$-tricalcium phosphate scaffold formed into the shape of the defect. The patient finally regained full oral function after about 12 months. It was the first clinical case where ectopic bone was produced using autologous ASCs in microvasc ular rec onstruction surgery. The suc cessful outc ome of this clinical case paves the way for extensive clinical trials using ASCs in custom-made implants for the reconstruction craniofacial bone defects.

The results of early studies are inspining, but they only offered level 4 and 5 data, and lack signific ant power to impel clinical practice. Larger scale researches such as prospective, randomized control trials must be executed to verify these findings.

\section{Conclusions}

The field has made huge strides toward engineering bone tissue replacements from the development of Wolff's law in the late 19th century to the principles of mechanobiology applied to stem cell osteogenesis. ASC s a re easy to isolate through liposuction, available in large quantities, and a abundant cell type with the capability to undergo robust osteogenesis, which makes them an exciting candidate in vivo studies. Furthermore, the ability of undergoing osteogenic differentiation without any stimulation when seeded on an osteoconducive scaffold in vivo makes ASCs a promising candidate for bone tissue engineering. However, some studies showed that immunosuppressive capacity of the ASC s may favor the growth of tumor cells in some cases (121-122). Hence, further studies of the mechanism of osteogenic differentiation and ways to improve ASC osteo differentiation and verify the safety of using ASC s in the clinical procedure are required in the future.

\section{Acknowledgements}

This work was funded by National Natural Science Foundation of China (81071273, 31170929), Foundation for the Author of National Excellent Doctoral Dissertation of China (FANEDD 200977), Innovative Research Team of Education Department of Sic huan Province (13TD0038).

\section{References}

1 Vats A, Tolley NS, Polak JM, Buttery LD. Stem cells: sources and applications. Clin Otolaryngol Allied Sci. 2002;27:227-232.

2 Le Blanc K, Pittenger M. Mesenchymal stem cells: progress toward promise. Cytotherapy. 2005;7:36-45.

3 Zuk PA, Zhu M, Ashjian P, De Ugarte DA, Huang JI, Mizuno H, Alfonso ZC, Fraser JK, Benhaim P, Hedrick MH. Human adipose tissue is a source of multipotent stem cells. Mol Biol Cell. 2002;13 4279-4295.

4 Simmons PJ, Torok-Storb B. Identification of stromal cell precursors in human bone marrow by a novel monoclonal antibody, STRO-1. Blood. 1991;78:55-62.

5 Kuroda R, Ishida K, Matsumoto T, Akisue T, Fujioka H, Mizuno K, Ohgushi H, Wakitani S, Kurosaka M. Treatment of a fullthickness articular cartilage defect in the femoral condyle of an athlete with autologous bone-marrow stromal cells. Osteoarthritis Cartilage. 2007;15:226-231.

6 Liu Y, Shu XZ, Prestwich GD. Osteochondral defect repair with autologous bone marrow-derived mesenchymal stem cells in an injectable, in situ, cross-linked synthetic extracellular matrix. Tissue Eng. 2006;12:3405-3416.

7 Palou M, Priego T, Sánchez J, Rodríguez AM, Palou A, Picó C. Gene expression patterns in visceral and subcutaneous adipose depots in rats are linked to their morphologic features. Cell Physiol Biochem. 2009;24:547-556.

8 Schäffler A, Büchler C. Concise review: adipose tissue-derived stromal cells--basic and clinical implications for novel cell-based therapies. Stem Cells. 2007;25:818-827.

9 Zuk PA, Zhu M, Mizuno H, Huang J, Futrell JW, Katz AJ, Benhaim P, Lorenz HP, Hedrick MH. Multilineage cells from human adipose tissue: implications for cell-based therapies. 
Tissue Eng. 2001;7:211-228.

10 Ahn HH, Kim KS, Lee JH, Lee JY, Kim BS, Lee IW, Chun HJ, Kim $\mathrm{JH}$, Lee HB, Kim MS. In vivo osteogenic differentiation of human adipose-derived stem cells in an injectable in situ-forming gel scaffold. Tissue Eng Part A. 2009;15:1821-1832.

11 Cowan CM, Shi YY, Aalami OO, Chou YF, Mari C, Thomas R, Quarto N, Contag CH, Wu B, Longaker MT. Adipose-derived adult stromal cells heal critical-size mouse calvarial defects. Nat Biotechnol. 2004;22:560-567.

12 Mitchell JB, McIntosh K, Zvonic S, Garrett S, Floyd ZE, Kloster A, Di Halvorsen Y, Storms RW, Goh B, Kilroy G, Wu X, Gimble JM. Immunophenotype of human adipose-derived cells: temporal changes in stromal-associated and stem cell-associated markers. Stem Cells. 2006;24:376-385.

13 Dominici M, Le Blanc K, Mueller I, Slaper-Cortenbach I, Marini F, Krause D, Deans R, Keating A, Prockop Dj, Horwitz E. Minimal criteria for defining multipotent mesenchymal stromal cells. The international society for cellular therapy position statement. Cytotherapy. 2006;8:315-317.

14 Lin CS, Xin ZC, Deng $\mathrm{CH}$, Ning H, Lin G, Lue TF. Defining adipose tissue-derived stem cells in tissue and in culture. Histol Histopathol. 2010;25:807-815.

15 McIntosh K, Zvonic S, Garrett S, Mitchell JB, Floyd ZE, Hammill L, Kloster A, Di Halvorsen Y, Ting JP, Storms RW, Goh B, Kilroy $\mathrm{G}, \mathrm{Wu} X$, Gimble JM. The immunogenicity of human adiposederived cells: temporal changes in vitro. Stem Cells. 2006;24:12461253.

16 Yoshimura K, Shigeura T, Matsumoto D, Sato T, Takaki Y, Aiba-Kojima E, Sato K, Inoue K, Nagase T, Koshima I, Gonda K. Characterization of freshly isolated and cultured cells derived from the fatty and fluid portions of liposuction aspirates. J Cell Physiol. 2006;208:64-76.

17 Chen D, Zhao M, Mundy GR. Bone morphogenetic proteins. Growth Factors. 2004;22:233-241.

18 Gilboa L, Nohe A, Geissendörfer T, Sebald W, Henis YI, Knaus P. Bone morphogenetic protein receptor complexes on the surface of live cells: a new oligomerization mode for serine/threonine kinase receptors. Mol Biol Cell. 2000;11:1023-1035.

19 Heldin $\mathrm{CH}$, Miyazono K, ten Dijke P. TGF-beta signalling from cell membrane to nucleus through SMAD proteins. Nature. 1997; 390:465-471.

20 Ducy P, Zhang R, Geoffroy V, Ridall AL, Karsenty G. Osf2/Cbfa1: a transcriptional activator of osteoblast differentiation. Cell. 1997; 89:747-754.

21 Jadlowiec JA, Celil AB, Hollinger JO. Bone tissue engineering: recent advances and promising therapeutic agents. Expert Opin Biol Ther. 2003;3:409-423.

22 Kang Q, Sun MH, Cheng H, Peng Y, Montag AG, Deyrup AT, Jiang W, Luu HH, Luo J, Szatkowski JP, Vanichakarn P, Park JY, Li Y, Haydon RC, He TC. Characterization of the distinct orthotopic bone-forming activity of 14 BMPs using recombinant adenovirus-mediated gene delivery. Gene Ther. 2004;11:1312-
1320.

23 Urist MR. Bone morphogenetic protein: the molecularization of skeletal system development. J Bone Miner Res. 1997;12:343-346.

24 Aono A, Hazama M, Notoya K, Taketomi S, Yamasaki H, Tsukuda R, Sasaki S, Fujisawa Y. Potent ectopic bone-inducing activity of bone morphogenetic protein-4/7 heterodimer. Biochem Biophys Res Commun. 1995;210:670-677.

25 Israel DI, Nove J, Kerns KM, Kaufman RJ, Rosen V, Cox KA, Wozney JM. Heterodimeric bone morphogenetic proteins show enhanced activity in vitro and in vivo. Growth Factors. 1996;13: 291-300.

26 Shi YY, Nacamuli RP, Salim A, Longaker MT. The osteogenic potential of adipose-derived mesenchymal cells is maintained with aging. Plast Reconstr Surg. 2005;116:1686-1696.

27 Mie M, Ohgushi H, Yanagida Y, Haruyama T, Kobatake E Aizawa M. Osteogenesis coordinated in C3H10T1/2 cells by adipogenesis-dependent BMP-2 expression system. Tissue Eng. 2000;6:9-18.

28 Saito A, Suzuki Y, Ogata S, Ohtsuki C, Tanihara M. Accelerated bone repair with the use of a synthetic BMP-2-derived peptide and bone-marrow stromal cells. J Biomed Mater Res A. 2005;72: 77-82.

29 Li H, Dai K, Tang T, Zhang X, Yan M, Lou J. Bone regeneration by implantation of adipose-derived stromal cells expressing BMP-2. Biochem Biophys Res Commun. 2007;356:836-842.

30 Knippenberg M, Helder MN, Zandieh Doulabi B, Wuisman PI, Klein-Nulend J. Osteogenesis versus chondrogenesis by BMP-2 and BMP-7 in adipose stem cells. Biochem Biophys Res Commun. 2006;342:902-908

31 Lin Y, Tang W, Wu L, Jing W, Li X, Wu Y, Liu L, Long J, Tian W. Bone regeneration by BMP-2 enhanced adipose stem cells loading on alginate gel. Histochem Cell Biol. 2008;129:203-210.

32 Wodarz A, Nusse R. Mechanisms of Wnt signaling in development. Annu Rev Cell Dev Biol. 1998;14:59-88.

33 Cadigan KM, Nusse R. Wnt signaling: a common theme in animal development. Genes Dev. 1997;11:3286-3305.

34 Bergwitz C, Wendlandt T, Kispert A, Brabant G. Wnts differentially regulate colony growth and differentiation of chondrogenic rat calvaria cells. Biochim Biophys Acta. 2001;1538:129-140.

35 Fischer L, Boland G, Tuan RS. Wnt signaling during BMP-2 stimulation of mesenchymal chondrogenesis. J Cell Biochem. 2002; 84:816-831.

36 Westendorf JJ, Kahler RA, Schroeder TM. Wnt signaling in osteoblasts and bone diseases. Gene. 2004;341:19-39.

37 Deregowski V, Gazzerro E, Priest L, Rydziel S, Canalis E. Notch 1 overexpression inhibits osteoblastogenesis by suppressing Wnt/ beta-catenin but not bone morphogenetic protein signaling. J Biol Chem. 2006;281:6203-6210.

38 Chen JR, Lazarenko OP, Shankar K, Blackburn ML, Badger TM, Ronis MJ. A role for ethanol-induced oxidative stress in controlling lineage commitment of mesenchymal stromal cells through inhibition of Wnt/beta-catenin signaling. J Bone Miner Res. 2010; 
25:1117-1127.

39 Si W, Kang Q, Luu HH, Park JK, Luo Q, Song WX, Jiang W, Luo X, Li X, Yin H, Montag AG, Haydon RC, He TC. CCN1/Cyr61 is regulated by the canonical Wnt signal and plays an important role in Wnt3A-induced osteoblast differentiation of mesenchymal stem cells. Mol Cell Biol. 2006;26:2955-2964.

40 Stevens JR, Miranda-Carboni GA, Singer MA, Brugger SM, Lyons $\mathrm{KM}$, Lane TF. Wnt10b deficiency results in age-dependent loss of bone mass and progressive reduction of mesenchymal progenitor cells. J Bone Miner Res. 2010;25:2138-2147.

41 Arnsdorf EJ, Tummala P, Jacobs CR. Non-canonical Wnt signaling and $\mathrm{N}$-cadherin related beta-catenin signaling play a role in mechanically induced osteogenic cell fate. PLoS One. 2009;4: e5388.

42 Chang J, Sonoyama W, Wang Z, Jin Q, Zhang C, Krebsbach PH, Giannobile W, Shi S, Wang CY. Noncanonical Wnt-4 signaling enhances bone regeneration of mesenchymal stem cells in craniofacial defects through activation of p38 MAPK. J Biol Chem. 2007;282:30938-30948.

43 Lathia JD, Mattson MP, Cheng A. Notch: from neural development to neurological disorders. J Neurochem. 2008;107:1471-1481.

44 Leong KG, Gao WQ. The Notch pathway in prostate development and cancer. Differentiation. 2008;76:699-716.

45 Raya A, Koth CM, Büscher D, Kawakami Y, Itoh T, Raya RM, Sternik G, Tsai HJ, Rodríguez-Esteban C, Izpisúa-Belmonte JC. Activation of Notch signaling pathway precedes heart regeneration in zebrafish. Proc Natl Acad Sci U S A. 2003;100:11889-11895.

46 Løvschall H, Tummers M, Thesleff I, Füchtbauer EM, Poulsen K. Activation of the Notch signaling pathway in response to pulp capping of rat molars. Eur J Oral Sci. 2005;113:312-317.

47 Kadesch T. Notch signaling: the demise of elegant simplicity. Curr Opin Genet Dev. 2004;14:506-512.

48 Hilton MJ, Tu X, Wu X, Bai S, Zhao H, Kobayashi T, Kronenberg HM, Teitelbaum SL, Ross FP, Kopan R, Long F. Notch signaling maintains bone marrow mesenchymal progenitors by suppressing osteoblast differentiation. Nat Med. 2008;14:306-314.

49 Sciaudone M, Gazzerro E, Priest L, Delany AM, Canalis E. Notch 1 impairs osteoblastic cell differentiation. Endocrinology. 2003; 144:5631-5639.

50 Shindo K, Kawashima N, Sakamoto K, Yamaguchi A, Umezawa A, Takagi M, Katsube K, Suda H. Osteogenic differentiation of the mesenchymal progenitor cells, Kusa is suppressed by Notch signaling. Exp Cell Res. 2003;290:370-380.

51 Nofziger D, Miyamoto A, Lyons KM, Weinmaster G. Notch signaling imposes two distinct blocks in the differentiation of C2C12 myoblasts. Development. 1999;126:1689-1702.

52 Shen Q, Christakos S. The vitamin D receptor, Runx2, and the Notch signaling pathway cooperate in the transcriptional regulation of osteopontin. J Biol Chem. 2005;280:40589-40598.

53 Chillakuri CR, Sheppard D, Lea SM, Handford PA. Notch receptor-ligand binding and activation: insights from molecular studies. Semin Cell Dev Biol. 2012;23:421-428.
54 Miele L. Notch signaling. Clin Cancer Res. 2006;12:1074-1079.

55 Miele L, Golde T, Osborne B. Notch signaling in cancer. Curr Mol Med. 2006;6:905-918.

$56 \mathrm{Wu}$ L, Griffin JD. Modulation of Notch signaling by mastermindlike (MAML) transcriptional co-activators and their involvement in tumorigenesis. Semin Cancer Biol. 2004;14:348-356.

57 Grottkau BE, Chen XR, Friedrich CC, Yang XM, Jing W, Wu Y, Cai XX, Liu YR, Huang YD, Lin YF. DAPT enhances the apoptosis of human tongue carcinoma cells. Int J Oral Sci. 2009;1:81-89.

58 Iso T, Chung G, Hamamori Y, Kedes L. HERP1 is a cell typespecific primary target of Notch. J Biol Chem. 2002;277:6598-6607.

59 Iso T, Kedes L, Hamamori Y. HES and HERP families: multiple effectors of the Notch signaling pathway. J Cell Physiol. 2003;194: 237-255.

60 Nickoloff BJ, Qin JZ, Chaturvedi V, Denning MF, Bonish B, Miele L. Jagged-1 mediated activation of notch signaling induces complete maturation of human keratinocytes through NF-kappaB and PPARgamma. Cell Death Differ. 2002;9:842-855.

61 Ohazama A, Hu Y, Schmidt-Ullrich R, Cao Y, Scheidereit C, Karin M, Sharpe PT. A dual role for Ikk alpha in tooth development. Dev Cell. 2004;6:219-227.

62 Kadesch T. Notch signaling: the demise of elegant simplicity. Curr Opin Genet Dev. 2004;14:506-512.

63 Jing W, Xiong Z, Cai X, Huang Y, Li X, Yang X, Liu L, Tang W, Lin $Y$, Tian W. Effects of gamma-secretase inhibition on the proliferation and vitamin $\mathrm{D}(3)$ induced osteogenesis in adipose derived stem cells. Biochem Biophys Res Commun. 2010;392:442447.

64 Canalis E. Notch signaling in osteoblasts. Sci Signal. 2008;1:pe17.

65 Ingham PW, McMahon AP. Hedgehog signaling in animal development: paradigms and principles. Genes Dev. 2001;15: 3059-3087.

66 Nakamura T, Aikawa T, Iwamoto-Enomoto M, Iwamoto M, Higuchi Y, Pacifici M, Kinto N, Yamaguchi A, Noji S, Kurisu K, Matsuya T. Induction of osteogenic differentiation by hedgehog proteins. Biochem Biophys Res Commun. 1997;237:465-469.

67 Yuasa T, Kataoka H, Kinto N, Iwamoto M, Enomoto-Iwamoto M, Iemura S, Ueno N, Shibata Y, Kurosawa H, Yamaguchi A. Sonic hedgehog is involved in osteoblast differentiation by cooperating with BMP-2. J Cell Physiol. 2002;193:225-232.

68 Spinella-Jaegle S, Rawadi G, Kawai S, Gallea S, Faucheu C, Mollat P, Courtois B, Bergaud B, Ramez V, Blanchet AM, Adelmant G, Baron R, Roman-Roman S. Sonic hedgehog increases the commitment of pluripotent mesenchymal cells into the osteoblastic lineage and abolishes adipocytic differentiation. J Cell Sci. 2001; 114:2085-2094.

69 Wu X, Walker J, Zhang J, Ding S, Schultz PG. Purmorphamine induces osteogenesis by activation of the hedgehog signaling pathway. Chem Biol. 2004;11:1229-1238.

70 Ornitz DM, Marie PJ. FGF signaling pathways in endochondral and intramembranous bone development and human genetic disease. Genes Dev. 2002;16:1446-1465. 
71 Yu K, Ornitz DM. The FGF ligand-receptor signaling system in chondrogenesis, osteogenesis and vascularization of the endochondral skeleton. International Congress Series. 2007;1302:67-78.

72 Montero A, Okada Y, Tomita M, Ito M, Tsurukami H, Nakamura T, Doetschman T, Coffin JD, Hurley MM. Disruption of the fibroblast growth factor-2 gene results in decreased bone mass and bone formation. J Clin Invest. 2000;105:1085-1093.

73 Colvin JS, Feldman B, Nadeau JH, Goldfarb M, Ornitz DM. Genomic organization and embryonic expression of the mouse fibroblast growth factor 9 gene. Dev Dyn. 1999;216:72-88.

74 Garofalo S, Kliger-Spatz M, Cooke JL, Wolstin O, Lunstrum GP, Moshkovitz SM, Horton WA, Yayon A. Skeletal dysplasia and defective chondrocyte differentiation by targeted overexpression of fibroblast growth factor 9 in transgenic mice. J Bone Miner Res. 1999;14:1909-1915.

75 Liu Z, Xu J, Colvin JS, Ornitz DM. Coordination of chondrogenesis and osteogenesis by fibroblast growth factor 18. Genes Dev. 2002;16:859-869.

76 Ohbayashi N, Shibayama M, Kurotaki Y, Imanishi M, Fujimori T, Itoh N, Takada S. FGF18 is required for normal cell proliferation and differentiation during osteogenesis and chondrogenesis. Genes Dev. 2002;16:870-879.

77 Ferrari SL, Pierroz DD, Glatt V, Goddard DS, Bianchi EN, Lin FT, Manen D, Bouxsein ML. Bone response to intermittent parathyroid hormone is altered in mice null for \{beta\}-Arrestin2. Endocrinology. 2005;146:1854-1862.

78 Gardner MJ, van der Meulen MC, Demetrakopoulos D, Wright TM, Myers ER, Bostrom MP. In vivo cyclic axial compression affects bone healing in the mouse tibia. J Orthop Res. 2006;24: 1679-1686.

79 Rath B, Nam J, Knobloch TJ, Lannutti JJ, Agarwal S. Compressive forces induce osteogenic gene expression in calvarial osteoblasts. J Biomech. 2008;41:1095-1103.

80 Song G, Ju Y, Soyama H, Ohashi T, Sato M. Regulation of cyclic longitudinal mechanical stretch on proliferation of human bone marrow mesenchymal stem cells. Mol Cell Biomech. 2007;4:201210.

81 Yang X, Gong P, Lin Y, Zhang L, Li X, Yuan Q, Tan Z, Wang Y, Man Y, Tang H. Cyclic tensile stretch modulates osteogenic differentiation of adipose-derived stem cells via the BMP-2 pathway. Arch Med Sci. 2010;6:152-159.

82 Yang X, Cai X, Wang J, Tang H, Yuan Q, Gong P, Lin Y. Mechanical stretch inhibits adipogenesis and stimulates osteogenesis of adipose stem cells. Cell Prolif. 2012;45:158-166.

83 Hanson AD, Marvel SW, Bernacki SH, Banes AJ, van Aalst J, Loboa EG. Osteogenic effects of rest inserted and continuous cyclic tensile strain on hASC lines with disparate osteodifferentiation capabilities. Ann Biomed Eng. 2009;37:955-965.

84 Huang SC, Wu TC, Yu HC, Chen MR, Liu CM, Chiang WS, Lin KM. Mechanical strain modulates age-related changes in the proliferation and differentiation of mouse adipose-derived stromal cells. BMC Cell Biol. 2010;11:18
85 Arnsdorf EJ, Tummala P, Kwon RY, Jacobs CR. Mechanically induced osteogenic differentiation--the role of RhoA, ROCKII and cytoskeletal dynamics. J Cell Sci. 2009;122:546-553.

86 Gurkan UA, Akkus O. The mechanical environment of bone marrow: a review. Ann Biomed Eng. 2008;36:1978-1991.

87 Fröhlich M, Grayson WL, Marolt D, Gimble JM, Kregar-Velikonja N, Vunjak-Novakovic G. Bone grafts engineered from human adipose-derived stem cells in perfusion bioreactor culture. Tissue Eng Part A. 2010;16:179-189.

88 Li D, Tang T, Lu J, Dai K. Effects of flow shear stress and mass transport on the construction of a large-scale tissue-engineered bone in a perfusion bioreactor. Tissue Eng Part A. 2009;15:27732783.

89 Grayson WL, Bhumiratana S, Cannizzaro C, Chao PH, Lennon DP, Caplan AI, Vunjak-Novakovic G. Effects of initial seeding density and fluid perfusion rate on formation of tissue-engineered bone. Tissue Eng Part A. 2008;14:1809-1820.

90 Grayson WL, Martens TP, Eng GM, Radisic M, Vunjak-Novakovic G. Biomimetic approach to tissue engineering. Semin Cell Dev Biol. 2009;20:665-673.

91 David V, Guignandon A, Martin A, Malaval L, Lafage-Proust MH, Rattner A, Mann V, Noble B, Jones DB, Vico L. Ex Vivo bone formation in bovine trabecular bone cultured in a dynamic 3D bioreactor is enhanced by compressive mechanical strain. Tissue Eng Part A. 2008;14:117-126.

92 Duty AO, Oest ME, Guldberg RE. Cyclic mechanical compression increases mineralization of cell-seeded polymer scaffolds in vivo. J Biomech Eng. 2007;129:531-539.

93 Pelaez D, Huang CY, Cheung HS. Cyclic compression maintains viability and induces chondrogenesis of human mesenchymal stem cells in fibrin gel scaffolds. Stem Cells Dev. 2009;18:93-102.

94 Wall ME, Bernacki SH, Loboa EG. Effects of serial passaging on the adipogenic and osteogenic differentiation potential of adipose-derived human mesenchymal stem cells. Tissue Eng. 2007;13:1291-1298.

95 Zeng Q, Li X, Beck G, Balian G, Shen FH. Growth and differentiation factor-5 (GDF-5) stimulates osteogenic differentiation and increases vascular endothelial growth factor (VEGF) levels in fat-derived stromal cells in vitro. Bone. 2007;40:374-381.

96 Cowan CM, Aalami OO, Shi YY, Chou YF, Mari C, Thomas R, Quarto N, Nacamuli RP, Contag CH, Wu B, Longaker MT. Bone morphogenetic protein 2 and retinoic acid accelerate in vivo bone formation, osteoclast recruitment, and bone turnover. Tissue Eng. 2005;11:645-658.

97 Cho HH, Shin KK, Kim YJ, Song JS, Kim JM, Bae YC, Kim CD Jung JS. NF-kappaB activation stimulates osteogenic differentiation of mesenchymal stem cells derived from human adipose tissue by increasing TAZ expression. J Cell Physiol. 2010;223:168177.

98 Mesimäki K, Lindroos B, Törnwall J, Mauno J, Lindqvist C, Kontio R, Miettinen S, Suuronen R. Novel maxillary reconstruction with ectopic bone formation by GMP adipose stem cells. Int J 
Oral Maxillofac Surg. 2009;38:201-209.

99 Follmar KE, Decroos FC, Prichard HL, Wang HT, Erdmann D, Olbrich KC. Effects of glutamine, glucose, and oxygen concentration on the metabolism and proliferation of rabbit adiposederived stem cells. Tissue Eng. 2006;12:3525-3533.

Miyazaki M, Zuk PA, Zou J, Yoon SH, Wei F, Morishita Y, Sintuu C, Wang JC. Comparison of human mesenchymal stem cells derived from adipose tissue and bone marrow for ex vivo gene therapy in rat spinal fusion model. Spine (Phila Pa 1976). 2008;33(8):863-869.

101 Levi B, Longaker MT. Concise review: adipose-derived stromal cells for skeletal regenerative medicine. Stem Cells. 2011;29:576582.

102 Lin Y, Wang T, Wu L, Jing W, Chen X, Li Z, Liu L, Tang W, Zheng $X$, Tian W. Ectopic and in situ bone formation of adipose tissue-derived stromal cells in biphasic calcium phosphate nanocomposite. J Biomed Mater Res A. 2007;81:900-910.

103 Lee JH, Rhie JW, Oh DY, Ahn ST. Osteogenic differentiation of human adipose tissue-derived stromal cells (hASCs) in a porous three-dimensional scaffold. Biochem Biophys Res Commun. 2008; 370:456-460.

104 Hicok KC, Du Laney TV, Zhou YS, Halvorsen YD, Hitt DC, Cooper LF, Gimble JM. Human adipose-derived adult stem cells produce osteoid in vivo. Tissue Eng. 2004;10:371-380.

105 Juthamas R, Sorada K, Yasuhiko T, Siriporn D. Growth and osteogenic differentiation of adipose-derived and bone marrowderived stem cells on chitosan and chitooligosaccharide films. Carbohyd Polym. 2009;78:873-878.

106 Kang SW, Kim JS, Park KS, Cha BH, Shim JH, Kim JY, Cho DW, Rhie JW, Lee SH. Surface modification with fibrin/hyaluronic acid hydrogel on solid-free form-based scaffolds followed by BMP-2 loading to enhance bone regeneration. Bone. 2011;48:298306.

107 Prichard HL, Reichert WM, Klitzman B. Adult adipose-derived stem cell attachment to biomaterials. Biomaterials. 2007;28:936946.

108 Yuan H, Yang Z, De Bruij JD, De Groot K, Zhang X. Materialdependent bone induction by calcium phosphate ceramics: a 2.5-year study in dog. Biomaterials. 2001;22:2617-2623.

109 Knop C, Sitte I, Canto F, Reinhold M, Blauth M. Successful posterior interlaminar fusion at the thoracic spine by sole use of beta-tricalcium phosphate. Arch Orthop Trauma Surg. 2006;126: 204-210.

110 Cowan CM, Aalami OO, Shi YY, Chou YF, Mari C, Thomas R, Quarto N, Nacamuli RP, Contag CH, Wu B, Longaker MT. Bone morphogenetic protein 2 and retinoic acid accelerate in vivo bone formation, osteoclast recruitment, and bone turnover. Tissue Eng. 2005;11:645-658.

111 Conejero JA, Lee JA, Parrett BM, Terry M, Wear-Maggitti K,
Grant RT, Breitbart AS. Repair of palatal bone defects using osteogenically differentiated fat-derived stem cells. Plast Reconstr Surg. 2006;117:857-863.

112 Dudas JR, Marra KG, Cooper GM, Penascino VM, Mooney MP, Jiang S, Rubin JP, Losee JE. The osteogenic potential of adiposederived stem cells for the repair of rabbit calvarial defects. Ann Plast Surg. 2006;56:543-548.

113 Yoon E, Dhar S, Chun DE, Gharibjanian NA, Evans GR. In vivo osteogenic potential of human adipose-derived stem cells/poly lactide-co-glycolic acid constructs for bone regeneration in a rat critical-sized calvarial defect model. Tissue Eng. 2007;13:619-627.

114 Cui L, Liu B, Liu G, Zhang W, Cen L, Sun J, Yin S, Liu W, Cao Y. Repair of cranial bone defects with adipose derived stem cells and coral scaffold in a canine model. Biomaterials. 2007;28:54775486.

115 Lee SJ, Kang SW, Do HJ, Han I, Shin DA, Kim JH, Lee SH Enhancement of bone regeneration by gene delivery of BMP2/ Runx2 bicistronic vector into adipose-derived stromal cells. Biomaterials. 2010;31:5652-5659.

116 Yoshimura K, Sato K, Aoi N, Kurita M, Hirohi T, Harii K. Cell-assisted lipotransfer for cosmetic breast augmentation: supportive use of adipose-derived stem/stromal cells. Aesthetic Plast Surg. 2008;32:48-55.

117 Yoshimura K, Asano Y, Aoi N, Kurita M, Oshima Y, Sato K, Inoue K, Suga H, Eto H, Kato H, Harii K. Progenitor-enriched adipose tissue transplantation as rescue for breast implant complications. Breast J. 2010;16:169-175.

118 Yoshimura K, Sato K, Aoi N, Kurita M, Inoue K, Suga H, Eto H, Kato H, Hirohi T, Harii K. Cell-assisted lipotransfer for facial lipoatrophy: efficacy of clinical use of adipose-derived stem cells. Dermatol Surg. 2008;34:1178-1185.

119 Sanz-Ruiz R, Fernández-Santos E, Domínguez-Muñoa M, Parma R, Villa A, Fernández L, Sánchez PL, Fernández-Avilés F. Early translation of adipose-derived cell therapy for cardiovascular disease. Cell Transplant. 2009;18:245-254.

120 Lendeckel S, Jödicke A, Christophis P, Heidinger K, Wolff J, Fraser JK, Hedrick MH, Berthold L, Howaldt HP. Autologous stem cells (adipose) and fibrin glue used to treat widespread traumatic calvarial defects: case report. J Craniomaxillofac Surg 2004;32:370-373.

121 Yu JM, Jun ES, Bae YC, Jung JS. Mesenchymal stem cells derived from human adipose tissues favor tumor cell growth in vivo. Stem Cells Dev. 2008;17:463-473.

122 Cousin B, Ravet E, Poglio S, De Toni F, Bertuzzi M, Lulka H, Touil I, André M, Grolleau JL, Péron JM, Chavoin JP, Bourin P, Pénicaud L, Casteilla L, Buscail L, Cordelier P. Adult stromal cells derived from human adipose tissue provoke pancreatic cancer cell death both in vitro and in vivo. PLoS One. 2009;4:e6278. 